\section{Bottling up dissent}

Vera Rich reports on recent developments concerning dissidents in the USSR and Eastern Europe.

LEONID PI.YUSHCH, a former prisoner of conscience who was interned in the Dnepropetrovsk psychiatric penal institution, visited London recently. His presence formed a rallying point for all those concerned in the cause of human rights and freedom of thought in the USSR and the Comecon bloc.

Plyushch, a cybernetician who was arrested in 1972 for "anti-Soviet agitation and propaganda", was tried in his absence and interned as suffering from "creeping schizophrenia". His release was effected in 1975 following a massive campaign both from the mathematical and psychiatric communities abroad Speaking in his native Ukrainian, a medium of expression which he explained was itself a symptom of "dissidence" to Soviet forensic psychiatrists, Plyushch declared that he did not wish to recall the details of his incarceration-the massive doses of neuroleptic drugs, the ambience of the genuinely sick and the "doctors" whose white coats only partially covered their police uniforms.

In an interview with Nature he indicated he was concerned rather to campaign for those still in captivity, either his fellow internees in mental institutions or those who, like Vladimir Bukovskii or Semeon Gluzman, are now serving prison sentences for bringing the Soviet abuse of psychiatry to the attention of the world scientific community. Some 1,000 detainees, he estimated, are incarcerated in penal or ordinary mental institutions simply because their views on politics and human rights do not coincide with the official norms. Asked whether he had any regrets in his own case, Plyushch replied that, speaking with hindsight, he could now see that it would have been advisable to proceed more "cannily", to be less open and naive, and to make sure that the authorities had less opportunity to gather a dossier against him.

Having acted as a liaison officer between the movement for self-determination in his native Ukraine and the Sakharov human rights committee in Moscow, Plyushch gave some interest- ing new sidelights on the dissident movement. He stated that the campaign for human rights and civil liberties was primarily a movement of the scientific community, and had as yet little grass-roots following, thus differing sharply from the movement for religious liberty and the "national" movements in the Union (that is, nonRussian) Republics, which included all sections of the community. Only in certain specific areas, notably in West Ukraine (incorporated into the Soviet Union in 1939) is there a close link between the demand of the workers and peasants for better living standards and the campaign of the intellectuals for greater democratisation "on the Czech model".

As a cyberneticist himself, Plyushch stressed that the scientists in the dissident movement must put forward a "new kind of planning" if their ideas are to command the kind of mass support that he sees as the only sure foundation of democratisation.

The kind of union of workers and intellectuals which Plyushch advocates is an important feature of the new protest movement in Poland. Following the protests of workers in the Radom and Ursus plants against rising food prices, a defence committee was

\title{
A letter from the USSR
}

Nature has received this letter, addressed "to all scientists of the world":

Dear colleagues,

By this letter we want to call your attention to the tragic fate of biologist Sergei Kovalev. We want scientists to have a clear realisation of the conditions under which those who venture to protest against arbitrary rule are compelled to live in the Soviet Union. By the nature of their profession scientists strive for adequate cognition of the world. That is why we hope that it will be scientists who gain the best insight into certain features of the Soviet regime. This understanding could be of great importance.

Sergei Kovalev is a gifted scientist specialist in the field of heart and cell physiology. In December 1974 he was arrested, and in December 1975, after a year of imprisonment, sentenced to seven years of prison camps of severe regime to be followed by three years in exile.

Kovalev's alleged "crime" was that in accordance with his convictions he could not and did not obey an unwritten Soviet law: to keep silent about all acts of arbitrariness and injustice done by Soviet authorities. Kovalev was one of the first to join the Human Rights Movement. In May 1969 he entered "the Initiative Group" for protection of human rights. At a moment when "The Chronicle of Current Events" (a typewritten journal of political repression in the USSR) was savagely persecuted, Kovalev together with T. Velikanova and $T$. Khodorovich courageously announced that they would do their best to disseminate this journal since it gives true information about the violations of human rights in the USSR. All his activity in protection of human rights was imbued with noble spirit and humanism.

Sergei Kovalev committed no crime. In any open society he would be one of its most respected members. The Soviet authorities declared Kovalev a dangerous criminal. His imprisonment is not a mere limitation of freedom. In the camps they are trying to "rectify" Kovalev's convictions by isolation, hunger and humiliation. A renowned scientist is forced to do exhausting monotonous physical work, he is limited in correspondence (two letters a month), in visits of close relatives (one visit every four months at most, in practice still less). Malnutri- tion also is one of the "rectifying" measures; accordingly, during three and a half initial years Kovalev will not be allowed to receive parcels.

But all this does not seem enough. Kovalev is constantly persecuted by the camp administration. He is not given qualified medical treatment and has no possibility of curing a painful chronic disease which makes his prison life unbearable, hard enough as it already is.

We call scientists of the whole world to make use of every opportunity to draw public attention to the tragic fate of Sergei Kovalev.

We call scientists to appeal to Soviet legislative, governmental and party bodies on behalf of Sergei Kovalev.

We call biologists to withhold scientific contacts with the Soviet Union until Sergei Kovalev is released.

Andrfi Sakhapov, Valentin Turchin, Yuri Orlov, Yuri Mnyukh, Ninel PanFILOVA, YURI GOL'FAND, VENYAMIN Levich, Galina Salova, Yuri Gastev, AI EKSANDR Lavut, Tatyana VelikaNOVA, ALEKSANDR LERNER, TATYANA KhODOROVICH, IgOR MEL'CHUK, AleKsandr Korchak, Vladimir Albrekht, NaUm MEIman, EFrem Yankelevich, Elena BonNer, YURY Shikhanovich, MARK AZBEL'. 